\title{
NOTES
}

\section{Threshold of gross primary production for planktonic metabolic balance in the Southern Ocean: An experimental test}

\begin{abstract}
The proposed threshold planktonic gross primary production (GPP) value for $\mathrm{O}_{2}$ of $2.05 \mathrm{mmol} \mathrm{m}^{-3} \mathrm{~d}^{-1}$ separating net heterotrophic from net autotrophic communities in the Southern Ocean was tested experimentally using large mesocosms $\left(20 \mathrm{~m}^{3}\right)$. A set of eight mesocosms was moored in Johnson's Dock $\left(62^{\circ} 39.576^{\prime} \mathrm{S}, 60^{\circ} 22.408^{\prime} \mathrm{W}\right.$, Livingston Island, Antarctica) and a gradient of GPP was experimentally generated by imposing four light levels $(100 \%, 50 \%, 25 \%$, and $10 \%)$ in the presence or absence of nutrient additions $(0.1$ mol $\mathrm{NH}_{4} \mathrm{Cl}, 0.1 \mathrm{~mol}$ of $\mathrm{F}_{6} \mathrm{Na}_{2} \mathrm{Si}$, and $0.01 \mathrm{~mol} \mathrm{KH}_{2} \mathrm{PO}_{4}$ per mesocosm per day). The experimental treatments resulted in a broad range of chlorophyll $a$ (Chl $a)\left(0.31-93.5 \mathrm{mg} \mathrm{m}^{-3}\right)$ and GPP $\left(\mathrm{O}_{2}, 0.17-16.7 \mathrm{mmol} \mathrm{m}^{-3} \mathrm{~d}^{-1}\right)$. Community respiration (R) increased with increasing GPP, but not proportionately, resulting in a range of $P: R$ ratios ranging from 0.12 in intensely shaded communities to 1.3 in those receiving high irradiance and nutrient additions, with the compensation irradiance for community metabolism (i.e., percentage irradiance at $\mathrm{P}: \mathrm{R}=1$ ) being reached at $83 \%$ of the ambient irradiance. The experimental estimate of the threshold GPP for metabolic balance of the community investigated (i.e., $\mathrm{P}: \mathrm{R}=1$ ) was $2.2(\mathrm{SE} \pm 0.016) \mathrm{mmol} \mathrm{O}_{2} \mathrm{~m}^{-3} \mathrm{~d}^{-1}$, thereby validating the estimate of $2.05 \mathrm{mmol} \mathrm{O}_{2} \mathrm{~m}^{-3} \mathrm{~d}^{-1}$ derived in the past from comparative analyses of planktonic metabolism across the Southern Ocean. The validation of this threshold suggests that net heterotrophic planktonic communities may be more prevalent in the Southern Ocean than hitherto believed.
\end{abstract}

The Southern Ocean holds a significant potential for atmospheric $\mathrm{CO}_{2}$ uptake through thermodynamic processes (Watson and Orr 2003), yet its actual contribution to anthropogenic $\mathrm{CO}_{2}$ uptake is minor (Sabine et al. 2004), as models suggest that the biota in the Southern Ocean act as a $\mathrm{CO}_{2}$ source (Watson and Orr 2003) despite high reported spring blooms (e.g., Ducklow 2003). However, these blooms also support an important heterotrophic activity, carbon demands of which may exceed primary production at places (Odate et al. 2002; Agustí et al. 2004). Indeed, Agustí et al. (2004) report, on the basis of a comparative analysis of planktonic metabolism in the Southern Ocean, that planktonic respiration (R) exceeds gross primary production (GPP) in communities where GPP $<2 \mathrm{mmol} \mathrm{O}_{2} \mathrm{~m}^{-3} \mathrm{~d}^{-1}$. This finding is consistent with a general tendency for unproductive planktonic communities to be net heterotrophic (i.e., GPP $<$ R, Duarte and Agustí 1998). The existence of such thresholds is important to help delineate the area of the Southern Ocean supporting net heterotrophic communities at any one time, the metabolism of which must be supported by organic carbon excedents produced in the past or elsewhere, and to ascertain the critical inputs of limiting resources such as iron required to elevate GPP above this threshold, thereby yielding net autotrophic (GPP $>$ R) communities. However, Agustí et al. (2004) derived the GPP threshold of $\mathrm{O}_{2}$ of 2 mmol m-3 $\mathrm{d}^{-1}$ separating net autotrophic from net heterotrophic communities on the basis of a comparative analysis of reports of planktonic metabolism in the Southern Ocean, and the validity and predictive power of this threshold remains to be validated.

Recently, Duarte et al. (2004) reported a GPP threshold of $3.95 \mathrm{mmol} \mathrm{O}_{2} \mathrm{~m}^{-3} \mathrm{~d}^{-1}$ for GPP $=\mathrm{R}$ for the Mediterranean littoral, and validated this threshold through an independent mesocosm experiment where GPP was increased through a series of nutrient inputs. The experimental manipulation of planktonic communities in large mesocosms, albeit cumbersome, has been proven feasible in Antarctic waters (Agustí and Duarte 2000). We therefore used a series of large (20 $\mathrm{m}^{3}$ ) mesocosms to experimentally generate a gradient of GPP, and examined the metabolism of the planktonic community to test the proposed threshold GPP value of 2.05 mmol $\mathrm{O}_{2} \mathrm{~m}^{-3} \mathrm{~d}^{-1}$ separating net heterotrophic from net autotrophic communities (Agustí et al. 2004).

The ESEPAC (Estímulo Experimental de la Producción Antarctica Costera) experiment was conducted in Johnson's Dock $\left(62^{\circ} 39.576^{\prime} \mathrm{S} ; 60^{\circ} 22.408^{\prime} \mathrm{W}\right.$, Livingston Island, Antarctica), a sheltered bay receiving glacial melt water (Agustí and Duarte 2000). The experimental manipulations aimed at generating a gradient of GPP, encompassing the predicted threshold value of $2 \mathrm{mmol} \mathrm{O}_{2} \mathrm{~m}^{-3} \mathrm{~d}^{-1}$. As the communities present in these coastal waters are already productive ones (3.6 $\pm 1.0 \mathrm{mmol} \mathrm{O}_{2} \mathrm{~m}^{-3} \mathrm{~d}^{-1}$; Agustí and Duarte, 2000), the manipulations required to achieve the required gradient of GPP included changes in the growth conditions both to stimulate (nutrient additions) and depress (shading) primary production.

A floating platform holding eight mesocosms, consisting of large (14 m tall, $2.3 \mathrm{~m}$ diameter) ultraviolet (UV)-stabilized polyethylene bags, was moored in the deepest sector of the bay (about $25 \mathrm{~m}$ ) on 21 January 2000, with the top meter of the mesocosms extending above the water level as to avoid accidental intrusions of water by breaking waves. The mesocosms were filled with ambient, unscreened water (from a depth range of 0.5 to $3 \mathrm{~m}$ ) on 23 January, resulting in an average volume of $20 \mathrm{~m}^{3}$ in the mesocosms. The natural communities enclosed included grazers (mainly copepods, salps, and amphipods) at concentrations comparable to those in the ambient waters. The outer surface and top of duplicate mesocosms were covered with neutral screens 
Table 1. The average ( $\pm \mathrm{SE}$ ) gross community production (GPP), net community production (NCP), and community respiration (R) of communities exposed to different experimental treatments involving a variable effective incident irradiance (as a percentage of the $0-10 \mathrm{~m}$ average irradiance compared to that in ambient waters) and nutrient additions (or absence of additions) for $25 \mathrm{~d}$. $N=4$ for GPP, NCP, and $\mathrm{R} ; * N=9$ for $\mathrm{Chl} a$.

\begin{tabular}{|c|c|c|c|c|c|c|}
\hline$\%$ irradiance & Treatment & $\begin{array}{c}\text { GPP } \\
\left(\mathrm{mmol} \mathrm{O} \mathrm{m}^{-3} \mathrm{~d}^{-1}\right)\end{array}$ & $\begin{array}{c}\mathrm{NCP} \\
\left(\mathrm{mmol} \mathrm{O}_{2} \mathrm{~m}^{-3} \mathrm{~d}^{-1}\right)\end{array}$ & $\begin{array}{c}\mathrm{R} \\
\left(\mathrm{mmol} \mathrm{O} \mathrm{O}_{2} \mathrm{~m}^{-3} \mathrm{~d}^{-1}\right)\end{array}$ & $P: R$ & $\begin{array}{c}\text { Chl } a \\
\left(\mathrm{mg} \mathrm{Chl} a \mathrm{~m}^{-3}\right)\end{array}$ \\
\hline 6.5 & + nutrients & $0.17 \pm 0.06$ & $-1.16 \pm 0.43$ & $1.33 \pm 0.44$ & 0.12 & $1.75 \pm 0.04$ \\
\hline 17.3 & + nutrients & $0.96 \pm 0.58$ & $-0.59 \pm 0.85$ & $1.92 \pm 0.49$ & 0.50 & $2.39 \pm 0.24$ \\
\hline 47.5 & + nutrients & $1.49 \pm 0.48$ & $-1.45 \pm 0.58$ & $2.96 \pm 1.02$ & 0.50 & $5.51 \pm 0.26$ \\
\hline 100 & + nutrients & $7.30 \pm 3.71$ & $1.55 \pm 0.72$ & $5.74 \pm 3.10$ & 1.27 & $31.13 \pm 1.78$ \\
\hline 11.5 & - & $0.18 \pm 0.12$ & $-0.75 \pm 0.23$ & $0.95 \pm 0.29$ & 0.19 & $0.56 \pm 0.01$ \\
\hline 14.3 & - & $0.83 \pm 0.28$ & $-1.20 \pm 0.96$ & $2.06 \pm 1.03$ & 0.40 & $3.64 \pm 0.27$ \\
\hline 39.4 & - & $4.22 \pm 2.18$ & $0.99 \pm 1.29$ & $3.29 \pm 1.38$ & 1.28 & $18.33 \pm 1.23$ \\
\hline 100 & - & $1.54 \pm 0.53$ & $-0.13 \pm 0.43$ & $1.70 \pm 0.78$ & 0.91 & $2.72 \pm 0.14$ \\
\hline
\end{tabular}

transmitting $50 \%, 25 \%$, and $10 \%$ of the natural irradiance, and two additional mesocosms received the full ambient irradiance. One of the series of four mesocosms was amended with $\mathrm{Si}, \mathrm{P}$, and $\mathrm{N}$ in the form of ammonia, whereas the other series was not. On the basis of results from a pilot experiment (Agustí and Duarte 2000), nutrient-amended mesocosms received a daily addition of $0.1 \mathrm{~mol}$ of $\mathrm{N}\left(\right.$ as $\left.\mathrm{NH}_{4} \mathrm{Cl}\right)$, $0.1 \mathrm{~mol}$ of $\mathrm{Si}$ (as $\mathrm{F}_{6} \mathrm{Na}_{2} \mathrm{Si}$ ), and $0.01 \mathrm{~mol}$ of $\mathrm{P}\left(\right.$ as $\mathrm{KH}_{2} \mathrm{PO}_{4}$ ), using previously described procedures (Agustí and Duarte 2000). Nutrient additions were discontinued when ammonium concentrations approached $10 \mu \mathrm{mol} \mathrm{\textrm {L } ^ { - 1 }}$ to avoid potentially toxic levels, and were resumed when concentrations declined below this threshold. The experiment was conducted over a period of $25 \mathrm{~d}$, sufficient to allow the response of both the autotrophic and heterotrophic components of the microplanktonic community to the experimental conditions (Agustí and Duarte 2000). Additional details on the experimental procedures and the responses of the phytoplankton community are reported in Agawin et al. (2002).

Integrated $(0-12 \mathrm{~m})$ water samples for the determination of planktonic metabolism were collected at ca. 6-d intervals at about $0900 \mathrm{~h}$ local time, before nutrient additions. Integrated water samples were collected by slowly deploying the ballasted end of an acid-washed and prerinsed (three times) 5.4- $\mathrm{cm}$ internal diameter hose, thereby collecting a core of the upper $12 \mathrm{~m}$ of the water column. The end was then retrieved while preventing the contents of the tube from spilling over the opposite end, and the contents of the tube were emptied into an acid-washed, prerinsed 30-liter carboy by sliding the opposite end of the tube over the shoulder of the operator. Water samples for the determination of planktonic metabolic rates were carefully siphoned into 15 125$\mathrm{ml}$ narrow-mouthed Winkler bottles. Five of the bottles were immediately processed to measure the initial oxygen content present in the samples, and five transparent and five dark ones were incubated in situ (at a 3-m depth) for $24 \mathrm{~h}$. Dissolved oxygen concentration was measured using high-precision Winkler titration using a Metrohm-682 titrator for the potentiometric end-point detection (Oudot et al. 1988). The average coefficient of variation of dissolved oxygen concentration in replicated bottles was $0.39 \%$. $\mathrm{R}$ rates were determined from the oxygen change in the dark bottles, net community production (NCP) was determined from the oxygen change in the clear bottles, and GPP was calculated as the sum of R and NCP. Chlorophyll $a(\mathrm{Chl} a$ ) concentration was determined fluorometrically from integrated samples withdrawn at 2-d intervals.

The combination of high irradiance and nutrient additions as experimental treatments promoted large phytoplankton blooms, reaching a maximum Chl $a$ of $93.5 \mathrm{mg} \mathrm{m}^{-3}$, compared to concentrations of, on average ( \pm SE), $1.18 \pm 0.2$ $\mathrm{mg} \mathrm{m}^{-3}$ in the ambient waters. In contrast, shading to $11.5 \%$ of the ambient irradiance resulted, in the absence of nutrient inputs, in very low $\mathrm{Chl} a$ concentrations, $25 \%$ of those in the ambient waters $\left(0.31 \mathrm{mg} \mathrm{m}^{-3}\right)$. Hence, the experimental treatments generated a broad range of phytoplankton development, from abundances well below those in the ambient waters to large blooms, with the average $\mathrm{Chl} a$ concentrations ranging over 60 -fold among mesocosms (Table 1). The community was initially dominated by nanoautotrophs, leading to a dominance of large diatoms when significant blooms developed. Picoautotrophs comprised a modest fraction of the autotrophic community throughout, despite fast growth and efficient photosynthesis in some mesocosms (Agawin et al. 2002).

Planktonic metabolism responded to the experimental treatment within $10 \mathrm{~d}$ (Fig. 1). The development of blooms resulting from the combination of high irradiance and nutrient inputs leads to large increases in GPP, from $0.63 \mathrm{mmol}$ $\mathrm{O}_{2} \mathrm{~m}^{-3} \mathrm{~d}^{-1}$ at the start of the experiment to a maximum of $16.7 \mathrm{mmol} \mathrm{O}_{2} \mathrm{~m}^{-3} \mathrm{~d}^{-1}$ (Fig. 1). The development of blooms leads to a skewed distribution of planktonic metabolism within individual mesocosms (Fig. 1), as reflected in high standard errors about mean values (Table 1 ). The average GPP was closely $\left(R^{2}=0.98, p<0.05\right)$ correlated with the average Chl $a$ of the community (Fig. 2), and community respiration increased with increasing GPP $\left(R^{2}=0.90, p<\right.$ 0.05, Fig. 2).

Intense shading resulted in low GPP, with average values fourfold below the initial GPP of the community enclosed in mesocosms shaded below 14\% of the ambient irradiance (Fig. 1, Table 1), but community respiration did not decline proportionately (Table 1 ), resulting in a range of $\mathrm{P}: \mathrm{R}$ ratios ranging from 0.12 in intensely shaded communities to 1.3 in those receiving high irradiance. Indeed, the $\mathrm{P}: \mathrm{R}$ ratio of the community was very sensitive to shading, declining significantly with increasing shading (Fig. 3), such that the compensation irradiance for community metabolism (i.e., per- 


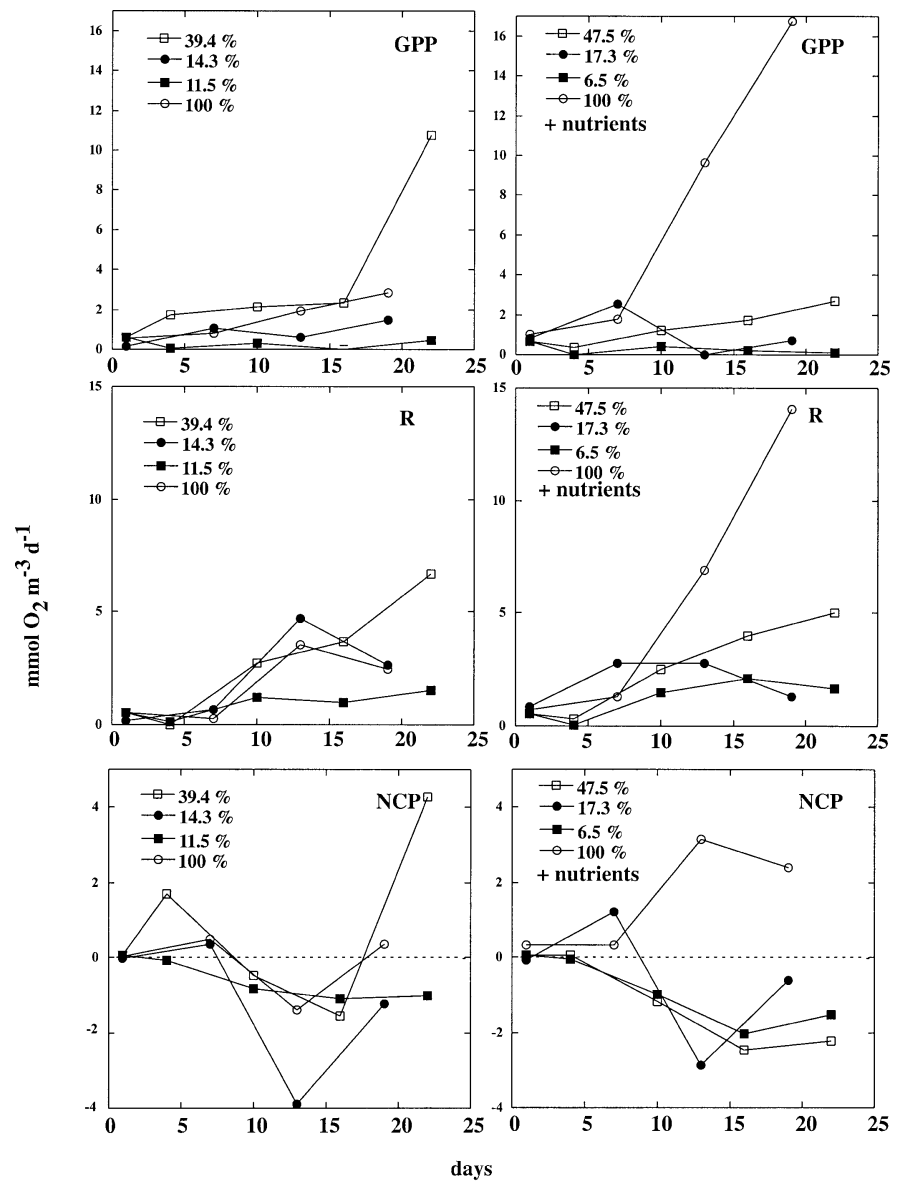

Fig. 1. Time series of gross primary production (GPP), community respiration $(\mathrm{R})$, and net community production $(\mathrm{NCP})$ for an Antarctic phytoplankton community enclosed in mesocosms subject to a gradient of incident irradiance and nutrient inputs. Experimental treatments are indicated in the inserts.

centage irradiance at $\mathrm{P}: \mathrm{R}=1$ ) was located at, on average, $83 \%( \pm 12 \%)$ of the ambient irradiance (Fig. 3$)$.

The $\mathrm{P}: \mathrm{R}$ ratio of the communities increased nonlinearly with increasing GPP to reach asymptotic values around 1.3 at high GPP (Fig. 4). The initial, linear slope of this relationship intercepted the line of metabolic balance (i.e., $\mathrm{P}: \mathrm{R}$ $=1$ ) at a GPP of $2.2 \pm 0.016 \mathrm{mmol} \mathrm{O}_{2} \mathrm{~m}^{-3} \mathrm{~d}^{-1}$ (Fig. 4), which represents, therefore, the experimentally derived estimate of the threshold GPP for metabolic balance of the Antarctic community.

The experimental treatments applied successfully generated a broad range in plantkonic metabolism, fully encompassing the range of $\mathrm{R}$, but with reaching a maximum GPP half of that reported across the Southern Ocean (Arístegui et al. 1996; Agustí et al. 2004). The experiment revealed a close relationship between GPP and phytoplankton Chl $a$ concentration, as well as a close relationship between GPP and $\mathrm{R}$, supporting previous reports for communities in the Southern Ocean (Odate et al. 2002; Agustí et al. 2004) and elsewhere (Duarte and Agustí 1998; Williams 1998; Robinson and Williams 2005). Yet, GPP and R did not vary
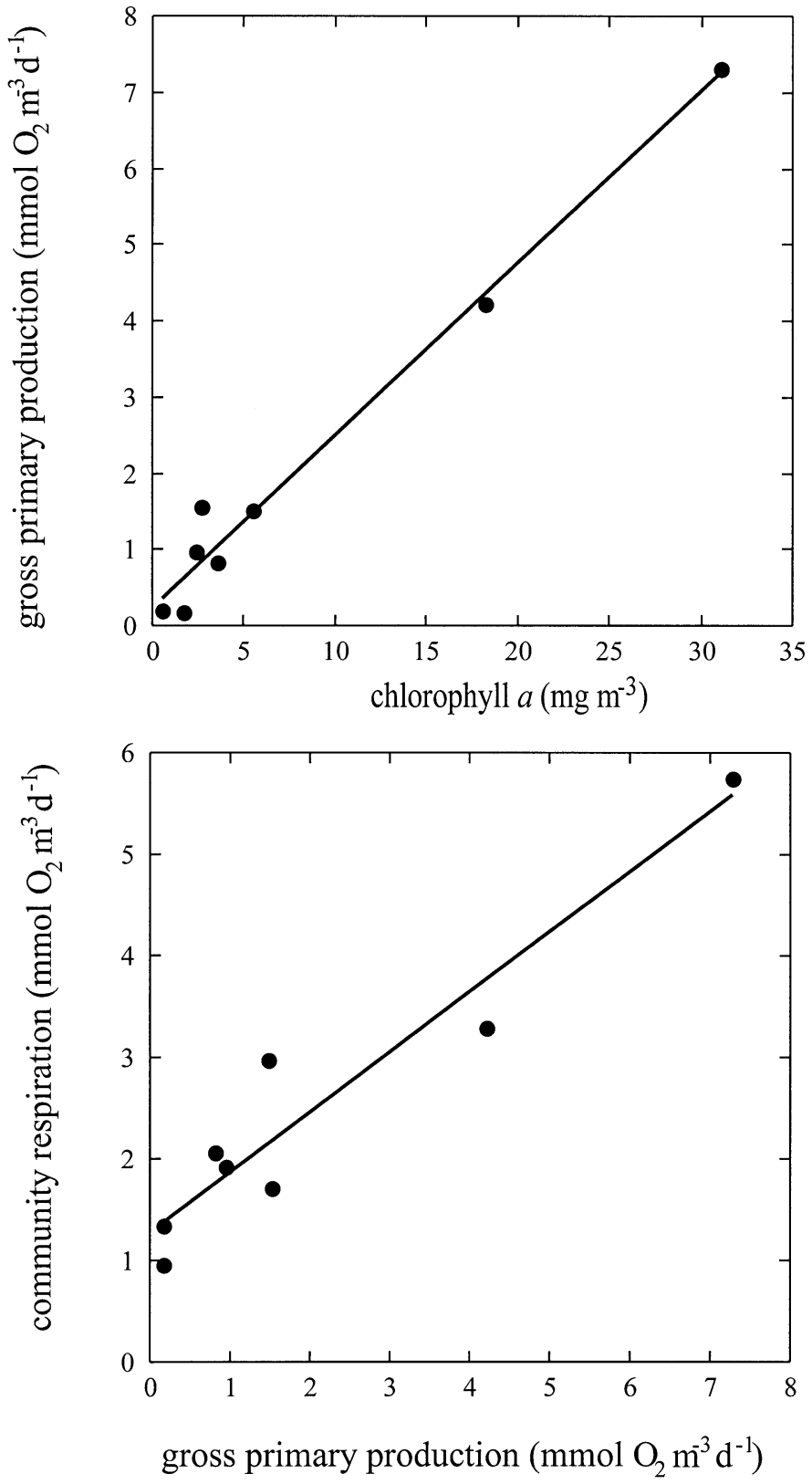

Fig. 2. (a) The relationships between the average chlorophyll $a$ concentration and the average gross primary production of the communities within the different mesocosms; (b) and between the average community respiration and the average gross primary production of the communities within the different mesocosms. Solid lines represent the fitted regression linear regression equations: (a) $\mathrm{GPP}=0.22+0.22( \pm 0.01) \mathrm{Chl} a, R^{2}=0.98, p<0.0001$; and (b) $\mathrm{R}=1.26+0.59( \pm 0.07) \mathrm{GPP}, R^{2}=0.90, p<0.0002$.

proportionately, as the average $\mathrm{P}: \mathrm{R}$ ratio varied an order of magnitude across the experimental conditions tested.

Highly shaded communities were not only unproductive, but also supported average community respiration rates about eight times in excess of their average GPP, whereas GPP exceeded $\mathrm{R}$ in highly productive communities by about $30 \%$. Indeed, the overall positive relationship between the $\mathrm{P}: \mathrm{R}$ ratio and the percentage irradiance reaching the water 


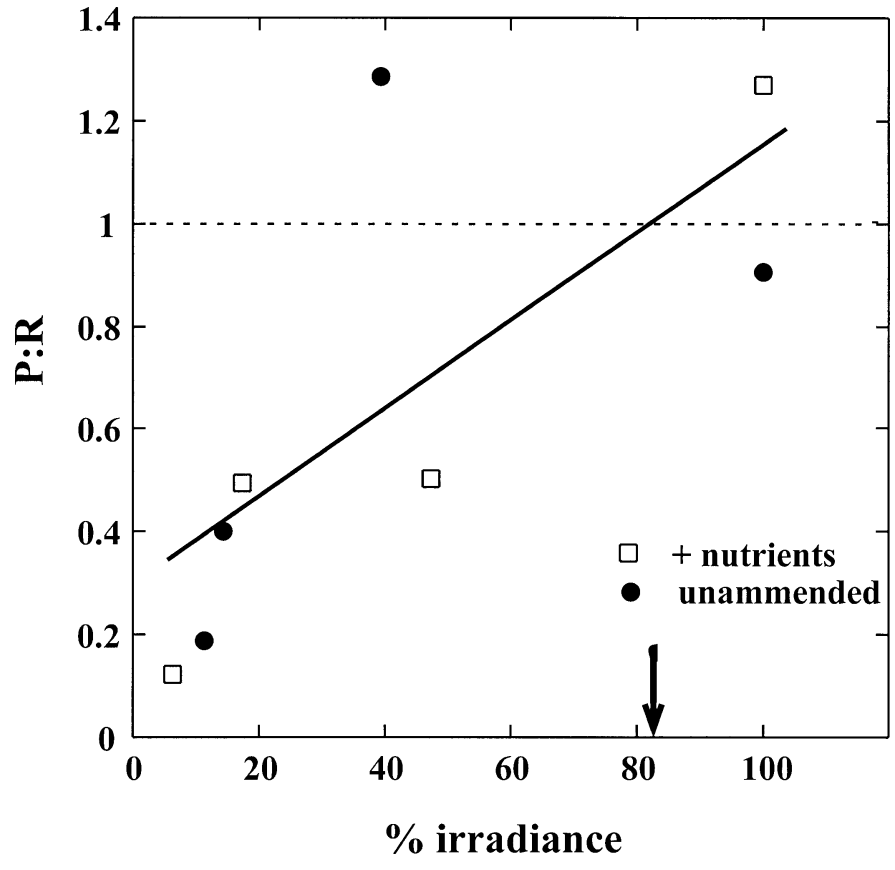

Fig. 3. The relationship between the average $\mathrm{P}: \mathrm{R}$ ratio for the communities within the different mesocosms and the percentage of the ambient irradiance $(0-10 \mathrm{~m})$ received within the mesocosms, as derived from shading of the mesocosms. The dotted line shows the line at metabolic balance $(\mathrm{P}: \mathrm{R}=1)$, the solid line shows the fitted regression equation $\left(\mathrm{P}: \mathrm{R}=0.27 \%+0.008 \%\right.$ irradiance; $R^{2}=$ $0.49, p<0.05)$, and the arrow indicates the compensation irradiance for community metabolism (i.e., $\mathrm{P}: \mathrm{R}=1$ ), the intercept between the dotted and solid lines.

column of the mescosms, relative to that in the ambient waters, suggested a light compensation irradiance of $83 \%$ $( \pm 12 \%)$ of the ambient irradiance, which corresponded to a $0-10-\mathrm{m}$ average daily maximal instantaneous irradiance of $340 \mu \mathrm{mol}$ quanta $\mathrm{m}^{-2} \mathrm{~s}^{-1}$. This finding suggests that the metabolism of planktonic communities in the Southern Ocean is highly sensitive to reduced irradiance, with the light compensation for balanced community metabolism being much higher, by a factor of 10 , than the corresponding light compensation irradiance for photosynthesis (Agawin et al. 2002), which only considers losses within the autotrophic compartment of the community. A deteriorated light environment, such as possibly derived from deep mixing, which is common in Antarctic waters (Mitchell et al. 1991; Mura et al. 1995; Agawin et al. 2002), or the presence of glaciar flour in coastal waters (cf. Agustí and Duarte 2000), should, therefore, lead to net heterotrophic metabolism.

The $\mathrm{P}: \mathrm{R}$ ratio of the community increased with increasing GPP, as predicted by Agustí et al. (2004), consistent with results across other aquatic ecosystems (Duarte and Agustí 1998). The threshold GPP value for metabolic balance (i.e., GPP at $\mathrm{P}: \mathrm{R}=1$ ) was experimentally determined at $2.2 \pm$ $0.016 \mathrm{mmol} \mathrm{O}_{2} \mathrm{~m}^{-3} \mathrm{~d}^{-1}$, remarkably close to the estimate of $2.05 \mathrm{mmol} \mathrm{O}_{2} \mathrm{~m}^{-3} \mathrm{~d}^{-1}$ derived by Agustí et al. (2004) on the basis of a comparative analysis of reports of planktonic metabolism across the Southern Ocean. This agreement,

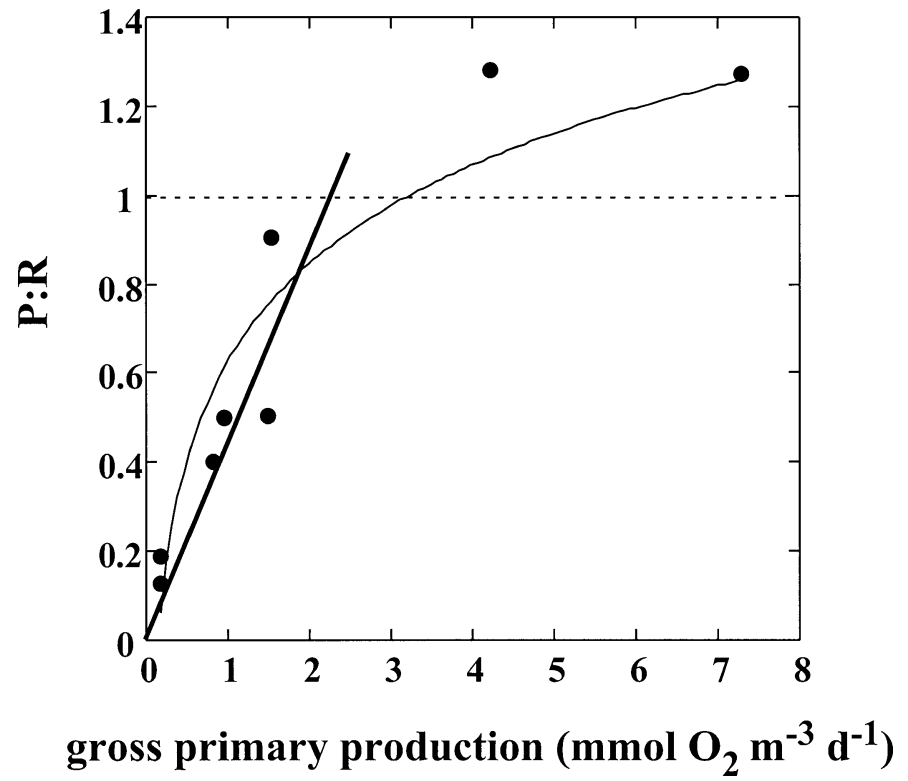

Fig. 4. The relationship between the $\mathrm{P}: \mathrm{R}$ ratio and the average gross primary production (GPP) of the planktonic communities within the different mesocosms. Solid lines represent the fitted semilogarithmic regression equation (thin solid line, $\mathrm{P}: \mathrm{R}=0.62+$ $0.73 \log$ GPP, $\left.R^{2}=0.86, p<0.05\right)$, and the fitted initial linear slope of the relationship (thick line, P:R $=0.08+0.41 \mathrm{GPP}, R^{2}$ $=0.75, p<0.05)$. The dotted line represents the line at metabolic balance $(\mathrm{P}: \mathrm{R}=1)$.

therefore, validates the existence of a threshold GPP of about $2 \mathrm{mmol} \mathrm{O} \mathrm{m}^{-3} \mathrm{~d}^{-1}$, below which Southern Ocean planktonic communities remain, on average, net heterotrophic (Agustí et al. 2004). This threshold value is close, but somewhat higher than the general threshold of $1.1 \mathrm{mmol} \mathrm{O}_{2} \mathrm{~m}^{-3} \mathrm{~d}^{-1}$ reported for open ocean communities (Duarte and Agustí 1998), also independently validated (Duarte et al. 2001; González et al. 2001), and well below threshold values reported for temperate coastal ecosystems $\left(3.95 \mathrm{mmol} \mathrm{O}_{2} \mathrm{~m}^{-3}\right.$ $\mathrm{d}^{-1}$ in the Mediterranean littoral, Duarte et al 2004; Hopkinson and Smith 2005), which receive substantial organic carbon inputs from land, thereby raising heterotrophic metabolism. Analysis of the relationship between volumetric GPP and $\mathrm{R}$ rates in the open ocean, on the basis of a large global data set (Robinson and Williams 2005), has further confirmed the existence of a threshold GPP. Reanalysis of the reduced major axis regression equation reported for the global data set (cf. Fig. 10 in Robinson and Williams 2005) revealed this threshold value to be $1.3 \mathrm{mmol} \mathrm{O}_{2} \mathrm{~m}^{-3} \mathrm{~d}^{-1}$ in the global data set, with confidence limits most likely encompassing the GPP threshold of $2 \mathrm{mmol} \mathrm{O}_{2} \mathrm{~m}^{-3} \mathrm{~d}^{-1}$ reported (Agustí et al. 2004), and now validated here, for the Southern Ocean. Indeed, the range of reported threshold GPP values ( 1.1 to $3.95 \mathrm{mmol} \mathrm{O}_{2} \mathrm{~m}^{-3} \mathrm{~d}^{-1}$ ) is surprisingly low, given the four order-of-magnitude range in GPP encompassed by the global data set (cf. Fig. 10 in Robinson and Williams 2005).

The threshold GPP of about $2 \mathrm{mmol} \mathrm{O}_{2} \mathrm{~m}^{-3} \mathrm{~d}^{-1}$ for balanced planktonic metabolism in the Southern ocean derived 
by Agustí et al. (2004) is likely to exceed local GPP over much of the Southern Ocean, except during the spring bloom, when high primary production rates and $\mathrm{C}$ sequestration can be recorded (Ducklow 2003). However, Southern Ocean planktonic communities remain unproductive over the winter period and much of the summer, so that primary production is low on an annual basis (Ducklow 2003). Yet, available information on the metabolic balance of planktonic community in the Southern Ocean suggests a dominance of net autotrophic communities (cf. Tables 1 and 2 in Agustí et al. 2004). However, Agustí et al. (2004) argue this to be a product of a bias toward the study of bloom conditions, underrepresenting the relative unproductive, low-biomass phytoplankton communities that prevail across the Southern Ocean even over much of the summer (Sullivan et al. 1993; Odate et al. 2002; Ducklow 2003), so that the prevalence of net heterotrophic planktonic communities in the Southern Ocean is likely to be, as suggested in the past (Odate et al. 2002; Agustí et al. 2004), greater than hitherto believed. Indeed, estimates of planktonic metabolism in the ocean tend to be biased toward highly active communities (cf. Robinson and Williams 2005), rendering estimates of global planktonic metabolism derived by upscaling from the still-meager empirical basis available uncertain (del Giorgio and Duarte 2002; Robinson and Williams 2005). The reported average net primary production in the Southern Ocean ranges between 37 in open waters and $100 \mathrm{mmol} \mathrm{C} \mathrm{m}{ }^{-2} \mathrm{~d}^{-1}$ in more coastal waters (Ducklow 2003), with the average mixed layer typically deeper than $50 \mathrm{~m}$ during the productive season (Longhurst 1998). Assuming GPP to be 1.74 times greater than net primary production in the Southern Ocean (Hendricks et al. 2005), our results suggest that GPP of planktonic communities across much of the Antarctic open waters is likely to be, on average, below the threshold for metabolic balance and, therefore, net heterotrophic. The strong correlation between GPP and Chl $a$ concentration reported here suggests that GPP may be predictable from remotely sensed properties, which would allow-if confirmed in the futurethe delineation from space of the area of the Southern Ocean supporting planktonic communities likely to be net heterotrophic $\left(\mathrm{GPP}<2 \mathrm{mmol} \mathrm{O}_{2} \mathrm{~m}^{-3} \mathrm{~d}^{-1}\right)$.

The successful experimental manipulation of planktonic communities using mesocosms to validate the threshold of GPP for balanced planktonic metabolism in the Southern Ocean derived from comparative analyses (Agustí et al. 2004) follows that to also validate a GPP threshold for the Mediterranean littoral (Duarte et al. 2004). Yet, the prevalence and regional variability of net heterotrophic planktonic communities in the open ocean remain controversial (Duarte and Agustí 1998; del Giorgio and Duarte 2002; Karl et al. 2003; Duarte and Prairie in press; Robinson and Williams 2005), rendering our understanding of the role of biota on the oceanic carbon budget uncertain. The growing evidence that thresholds of GPP derived from comparative analyses of survey data hold predictive power suggests that these thresholds can be used, after further validations for other regions, to elucidate the prevalence of net heterotrophy in the ocean.
Susana Agustí

Carlos M. Duarte

IMEDEA (CSIC-UIB)

Instituto Mediterráneo de Estudios Avanzados

Grupo de Oceanografía Interdiscplinar

Miquel Marqués, 21

07190 Esporles (Mallorca), Spain

\section{References}

Agawin, N. S. R., S. Agustí, And C. M. Duarte. 2002. Abundance of Antarctic picophytoplankton and their response to light and nutrient manipulation. Aquat. Microb. Ecol. 29:161172.

Agustí, S., And C. M. Duarte. 2000. Experimental induction of a large phytoplankton bloom in Antarctic coastal waters. Mar. Ecol. Prog. Ser. 206: 73-85.

, M. P. SatTA, AND M. P. Mura. 2004. Summer community respiration and pelagic metabolism in upper surface Antarctic waters. Aquat. Microb. Ecol. 35: 197-205.

Arístegui, J., M. F. Montero, S. Ballesteros, G. BasterreTXEA, AND K. V. LENNING. 1996. Planktonic primary production and microbial respiration measured by ${ }^{14} \mathrm{C}$ assimilation and dissolved oxygen changes in coastal waters of the Antarctic Peninsula during austral summer: Implications for carbon flux studies. Mar. Ecol. Progr. Ser. 132: 191-201.

Del Giorgio, P. A., AND C. M. DuARte. 2002. Respiration in the open ocean. Nature 420: 379-384.

Duarte, C. M., and S. Agustí. 1998. The $\mathrm{CO}_{2}$ balance of unproductive aquatic ecosystems. Science 281: 234-236.

,-- AND D. VAquÉ. 2004. Controls on planktonic metabolism in the Bay of Blanes, north-western Mediterranean litoral. Limnol. Oceanogr. 49: 2162-2170.

— J. J. Arístegui, N. González, S. Agustí, and R. Anadón. 2001. Evidence for a heterotrophic subtropical NE Atlantic. Limnol. Oceanogr. 46: 425-428.

- , AND Y. T. PRAIRIE. In press. Prevalence of net heterotrophic and $\mathrm{CO}_{2}$ emissions from aquatic ecosystems. Ecosystems.

DucKLOW, H. W. 2003. Biogeochemical provinces: Towards a JGOFS synthesis, p. 3-17. In M. J. R. Fasham (ed.), Ocean biogeochemistry. Springer.

González, N., R. Anadón, B. Mouriño, E. Fernández, B. Sinha, J. ESCÁNEZ, AND D. DE ARMAS. 2001. The metabolic balance of the planktonic community at the N. Atlantic Subtropiucal Gyre: The role of mesoscale instabilities. Limnol. Oceanogr. 46: $946-952$.

Hendricks, M. B., M. L. Bender, AND B. A. BARnett. 2005. Net and gross $\mathrm{O}_{2}$ production in the southern ocean from measure-

${ }^{1}$ Corresponding author (sagusti@uib.es).

\section{Acknowledgments}

We thank C. Cordón, commander of the R/V Hespérides, the crew-particularly maneuver and diver personnel-for their skilled assistance during the logistically complex ESEPAC experiment, the UGBO personnel involved in the experiment for professional technical assistance, and all scientists participating in the ESEPAC experiment for their contribution. We thank G. Carreras for excellent work with oxygen analysis and S. Pluvinage for chlorophyll analyses.

The authors were supported by sabbatical fellowships from the Spanish Ministry of Education and Science The ESEPAC experiment was funded by the Antarctic program of the Spanish Plan Nacional de I+D (ANT97-0273). 
ments of biological $\mathrm{O}_{2}$ saturation and its triple isotope composition. Deep-Sea Res. I 51: 1541-1561.

Hopkinson, C. S. JR., AND E. M. SMith. 2005. Estuarine respiration: An overview of benthic, pelagic and whole system respiration, p. 123-147. In P. A. del Giorgio and P. J. leB. Williams (eds.), Respiration in aquatic ecosystems. Oxford Univ. Press.

Karl, D. M., E. A. Laws, P. Morris, P. J. LeB. Williams, and S. EMERSON. 2003. Metabolic balance of the open sea. Nature 426: 32.

LONGHURST, A. R. 1998. Ecological geography of the sea. Academic Press.

Mitchell, B. G., E. A. Broody, O. Holm-Hansen, C. McClain, AND J. BISHOP. 1991. Light limitation of phytoplankton biomass and macronutrient utilization in the Southern Ocean. Limnol. Oceanogr. 36: 1662-1677.

Mura, M. P., M. P. SATTA, And S. Agustí. 1995. Water-mass influences on summer Antarctic phytoplankton biomass and community structure. Polar Biol. 15: 15-20.

Odate, T., K. Furuya, AND M. FukUChI. 2002. Photosynthetic oxygen production and community respiration in the Indian sector of the Antarctic Ocean during austral summer. Polar Biol. 25: 859-864.
Oudot, C., R. Gerard, P. Morin, and I. Gningue. 1988. Precise shipboard determination of total dissolved oxygen (Winkler procedure) for productivity studies with a commercial system. Limnol. Oceanogr. 33: 146-150.

Robinson, C., And P. J. LeB. Williams. 2005. Respiration and its measurement in surface waters, p. 147-180. In P. A. del Giorgio and P. J. leB. Williams [eds.], Respiration in aquatic ecosystems. Oxford Univ. Press.

SABINE, C. L., AND OTHERS. 2004. The oceanic sink for anthropogenic $\mathrm{CO}_{2}$. Science 305: 367-371.

Sullivan, C. W., K. R. Arrigo, C. R. McClain, J. C. Comiso, AND J. FIRESTONE. 1993. Distribution of phytoplankton blooms in the Southern Ocean. Science 262: 1832-1837.

Watson, A. J., And J. C. ORR. 2003. Carbon dioxide fluxes in the global ocean, p. 123-143. In M. J. R. Fasham [ed.], Ocean biogeochemistry. Springer-Verlag.

WiLliams, P. J. LEB. 1998. The balance of plankton respiration and photosynthesis in the open ocean. Nature 394: 55-57.

Received: 9 September 2004 Accepted: 27 January 2005

Amended: 9 March 2005

\section{Inhibitory effect of light on methane oxidation in the pelagic water column of a mesotrophic lake (Lake Biwa, Japan)}

\begin{abstract}
Methane oxidation was studied in mesotrophic lake water (Lake Biwa, Japan) under thermally stratified conditions. Methane oxidation rates at in situ concentrations were very low in lake water from the epilimnion and thermocline but were high in hypolimnetic water. Incubation under light conditions ranging from 4.1 to $57 \mu \mathrm{mol}$ photons $\mathrm{m}^{-2} \mathrm{~s}^{-1}$ resulted in decreased methane oxidation in hypolimnetic water. This inhibition was more severe as the light intensity increased. Addition of inorganic nitrogen (ammonium and nitrate) did not promote methane oxidation in the thermocline but inhibited it in the hypolimnion. Methane oxidation activity in the thermocline was observed after 1 month of incubation under dark conditions. Our results suggest that the inhibitory effect of light was bacteriostatic for the methanotrophic population. The different rates of methane oxidation between the hypolimnion and epilimnion/thermocline may explain the surface maximum of dissolved methane during the period of thermal stratification.
\end{abstract}

Aerobic methane oxidation in aquatic environments occurs at oxic sites adjacent to areas of high methane concentrations, i.e., sediment surface or oxic water, affecting the methane cycle. Methane oxidation also may contribute to oxygen consumption in the sediment and water column (Rudd and Hamilton 1978; Gelda et al. 1995).

The distribution and oxidation of dissolved methane in lake water have been well documented for eutrophic envi- ronments where the anoxic hypolimnion is developed permanently or seasonally due to chemical or thermal stratification. In such environments, the maximum methane concentration has been recorded in bottom water and the highest methane oxidation has been observed in the oxicanoxic boundary in the metalimnion (Kiene 1991) and even in the apparently anoxic deep water (Kiene 1991; Bastviken et al. 2002; Liikanen et al. 2002). On the other hand, surface water contains much less dissolved methane and shows low methane oxidizing activity compared with deeper layers.

The methane distribution in oligotrophic to mesotrophic lakes, where an oxic hypolimnion is maintained throughout a stratified period, has not been widely studied so far. A limited number of studies have demonstrated that in oligotrophic to mesotrophic lakes, methane concentrations in the hypolimnion are low due to active oxidation in the surface sediment and bottom water, whereas surface water shows a relatively high concentration of dissolved methane (Schmidt and Conrad 1993; Murase et al. 2003). Inflow of river water with high methane concentration (Murase et al. 2003) and transportation from the littoral sediment (Sakai et al. 2002; Murase et al. 2003) are potential sources of the surface methane maximum. The methane oxidation process in the water column of oligotrophic or mesotrophic lakes is poorly understood (Lidstrom and Somers 1984), although in marine waters of Cape Lookout Bight, Kelley (2003) reported that 